\title{
Salt water and silicon application on growth, chloroplastid pigments, chlorophyll fluorescence and beet production
}

\author{
Aplicación de agua salobre y silicio en el crecimiento, \\ pigmentos cloroplastídicos, fluorescencia de clorofila \\ y producción de remolacha
}

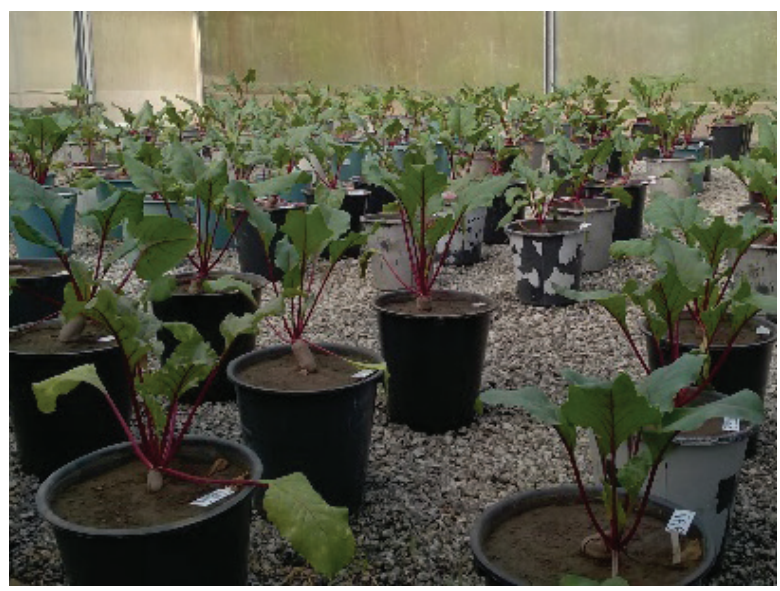

JOSÉ SEBASTIÃO DE MELO-FILHO'

TOSHIK IARLEY DA SILVA ${ }^{2}$

ANDERSON CARLOS DE MELO GONÇALVES ${ }^{3}$

LEONARDO VIEIRA DE SOUSA ${ }^{1}$

MÁRIO LENO MARTINS VÉRAS ${ }^{2,4}$

THIAGO JARDELINO DIAS ${ }^{1}$

\begin{abstract}
In recent years, the use of saline water in agriculture has become an alternative mainly because of water scarcity. However, plants do not tolerate high salt contents; so, the use of salt stress attenuators could enable saline water usage in agriculture. This study aimed to assess the effect of saline water and silicon applications on growth, chloroplastid pigments, chlorophyll fluorescence a and beet production. The experiment was conducted with complete randomized blocks in a $5 \times 5$ combined factorial arrangement according to the Central Composite of Box experiment matrix for the electrical conductivity in the irrigation water (ECW) and silicon doses (Si), with minimum (- $\alpha$ ) and maximum ( $\alpha$ ) values from 0.5 to $6.0 \mathrm{dS} \mathrm{m}^{-1}$ and from 0.00 to $18.16 \mathrm{~mL} \mathrm{~L}^{-1}$, totaling nine treatments, with four replicates and three plants per plot. The irrigation water ECw increase reduced growth and beet production, but the chlorophyll contents, biomass and fluorescence production were not affected by salinity. Silicon applications via the soil increased growth and chlorophyll fluorescence a but did not reduce the harmful effect of the salt stress. The irrigation water ECw above $0.50 \mathrm{dS} \mathrm{m} \mathrm{m}^{-1}$ negatively affected the beet crop. The silicon dose of $9.08 \mathrm{~mL} \mathrm{~L}^{-1}$ is the most recommended application.
\end{abstract}

Additional keywords: Beta vulgaris L.; abiotic stress; potassium silicate; photosynthesis.

Federal University of Paraíba, Department of Plant Science and Environmental Sciences, Areia (Brazil). ORCID MeloFilho, J.S.: 0000-0003-3005-2795; ORCID Sousa, L.V.: 0000-0001-5846-3399; ORCID Dias, T.J.: 0000-0002-7843-6184

2 Federal University of Viçosa, Department of Plant Science, Viçosa (Brazil). ORCID Silva, T.I.: 0000-0003-0704-2046; ORCID Véras, M.L.M.: 0000-0001-5968-4564

3 Federal University of Roraima, Department of Plant Science, Roraima (Brazil). ORCID Gonçalves, A.C.M.: 0000-00034151-1192

${ }_{4}^{4}$ Corresponding author. mario.veras1992@gmail.com 


\section{RESUMEN}

En los últimos años el uso de aguas salinas en la agricultura es una alternativa, principalmente en virtud de la escasez hídrica. Sin embargo, las plantas no toleran altos niveles de sales, por lo que el uso de atenuadores de estrés salino puede ser una estrategia para posibilitar el uso de aguas salinas en la agricultura. En este sentido, este trabajo tiene como objetivo evaluar el efecto de aguas salinas y aplicación de silicio sobre el crecimiento, pigmentos cloroplatísdicos, fluorescencia de la clorofila a y producción de remolacha. El experimento fue conducido en un diseño de bloques al azar, en factorial $5 \times 5$, referente a cinco niveles de conductividad eléctrica del agua de riego (CEa): $\left(0,5 ; 1,3 ; 3,25 ; 5,2\right.$ y $\left.6 \mathrm{dS} \mathrm{m}^{-1}\right)$ y cinco dosis de silicio $\left(0,00 ; 2,64 ; 9,08 ; 15,52\right.$ y $\left.18,16 \mathrm{~mL} \mathrm{~L}^{-1}\right)$, combinadas según la matriz experimental Compuesto Central de Box, con cuatro repeticiones y tres plantas por parcela. El aumento de la conductividad eléctrica en el agua de riego reduce el crecimiento y la producción de remolacha, pero los índices de clorofila, la producción de biomasa y la fluorescencia no están influenciados por el riego con aguas salinas. La aplicación de silicio a través del suelo promueve un incremento en el crecimiento y la fluorescencia de la clorofila a, sin embargo, no reduce el efecto nocivo del estrés salino. La conductividad eléctrica en el agua de riego por encima de $0,50 \mathrm{dS} \mathrm{m}^{-1}$ es suficiente para afectar negativamente el cultivo de la remolacha y la dosis de $9,08 \mathrm{ml} \mathrm{L}^{-1}$ de silicio es la más recomendada para su aplicación.

Palabras clave adicionales: Beta vulgaris L.; abiotic estrés; potasio silicato; photosynthesis.

Received for publication: 10-10-2018 Accepted for publication: 29-11-2019

INTRODUCTION

The agronomic performance of crops depends on edaphoclimatic factors, which are balanced under optimal conditions. Crops are subject to various types of biotic stresses (pests and diseases) and abiotic stress, isolated or combined. But in recent years, high contents of salts in water and in soil have become a significant problem in agriculture, especially in arid and semi-arid regions (Syvertsena and Garcia-Sanchez, 2014).

In arid and semi-arid regions, low rainfall and irregularity in rainfall mean that supplementary irrigation is almost mandatory, which, along with the need to expand cultivated areas, make low-quality water an alternative for irrigation (Lima et al., 2014).

Plants behave differently when saline water is used, and sensitivity to salinity depends on various factors, such as variety and plant exposure time (Pedrotti et al., 2015). When subjected to salt stress, plants experience change at the cellular level, including destruction of root plasma membrane and ionic stress on stem cells (Reis et al., 2016); therefore, a major symptom is stomatal closure, with a consequent lower photosynthetic activity, causing decreases in growth and productivity (Fraire-Velázquez and Balderas Hernández, 2013; Reis et al., 2016).
In recent years, one of the strategies to reduce the harmful effects of salt stress is using fertilization with silicon (Sahebi et al., 2016). Studies indicate that silicon can increase plant tolerance to salt stress since absorption of $\mathrm{K}$ and $\mathrm{Ca}$ ions contributes to the maintenance of $\mathrm{K}$ and $\mathrm{Na}$ contents in plants; however, mechanisms that contribute to increased tolerance to salt stress have not been discovered (Dias and Blanco, 2010; Shi et al., 2013; Castellano et al., 2016)

There are a few studies on some of the effects of Si in plants. These studies have shown that this element could mitigate the deleterious effects of salts in plants, but, for beets, there is little research that elucidates attenuator effect on salt stress. Thus, this study aimed to evaluate the effect of saline water and silicon applications on growth, chloroplastid pigments, fluorescence chlorophyll a and beet production.

\section{MATERIAL AND METHODS}

This experiment was conducted from January to March, 2018 in a greenhouse located in the Fruit sector belonging to the Federal University of Paraíba in Areia-PB, Brazil, located at 6 $6^{\circ} 1^{\prime} 47^{\prime \prime}$ and $7^{\circ} 02^{\prime} 04^{\prime \prime}$ 
South latitude and West longitude, 35 $34^{\prime} 13^{\prime \prime}$ and 3548'28" Greenwich meridian.

The experiment design used randomized blocks and a $5 \times 5$ factorial arrangement, combined according to the Central Composite of Box experiment matrix (Mateus et al., 2011) for the electrical conductivity of the irrigation water $(\mathrm{ECW})$ and silicon doses $(\mathrm{Si})$, with minimum values $(-\alpha)$ and maximum values $(\alpha)$

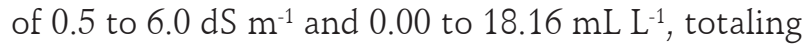
nine treatments, with four replicates and three plants per plot (Tab. 1).

Table 1. Combinations of treatments with the central compound matrix of box.

\begin{tabular}{|c|c|c|c|}
\hline \multicolumn{2}{|c|}{ Levels } & \multicolumn{2}{c|}{ Doses } \\
\hline $\mathrm{Si}$ & $\mathrm{ECw}$ & $\mathrm{Si}$ & $\mathrm{ECw}$ \\
\hline-1 & -1 & 2.64 & 1.30 \\
\hline-1 & 1 & 2.64 & 5.20 \\
\hline 1 & -1 & 15.52 & 1.30 \\
\hline 1 & 1 & 15.52 & 5.20 \\
\hline$-\alpha$ & 0 & 0.00 & 3.25 \\
\hline$\alpha$ & 0 & 18.16 & 3.25 \\
\hline 0 & $\alpha$ & 9.08 & 6.00 \\
\hline 0 & $-\alpha$ & 9.08 & 0.50 \\
\hline 0 & 0 & 9.08 & 3.25 \\
\hline
\end{tabular}

Beet $\mathrm{cv}$. Wonder seedlings were grown in trays and planted in pots with a $22 \mathrm{~cm}$ top diameter, $16 \mathrm{~cm}$ bottom diameter, $18 \mathrm{~cm}$ height, $8 \mathrm{dm}^{3}$ volumetric capacity, and $1 \mathrm{~cm}$ circular holes in the bottom to allow better root aeration and percolation of excess water.

The containers were filled with horizon A soil, collected at a depth of $0-20 \mathrm{~cm}$, classified as Planossolo Háplico Eutrófico êndico/Alfisol (Embrapa 2014). The chemical and physical characteristics (Tab. 2) were analyzed according to the methodology of Embrapa (2014). The soil was air dried, homogenized, and placed in containers accommodated previously with screen (tulle fabric) and $200 \mathrm{~g}$ of crushed rock, while preventing the soil from coming out of the holes in the bottom.

The plants were irrigated daily, bringing the soil moisture to about $80 \%$ of field capacity (CC). The different $\mathrm{ECw}$ were obtained by with the salts $\mathrm{NaCl}$, $\mathrm{CaCl}_{2} 2 \mathrm{H}_{2} \mathrm{O}$ and $\mathrm{MgCl}_{2} 6 \mathrm{H}_{2} \mathrm{O}$, at a ratio of 7:2:1 according to the characteristics (Tab. 3). Irrigation with

Table 2. Chemical and physical characteristics of the soil.

\begin{tabular}{|l|c|}
\hline \multicolumn{2}{|c|}{ Chemicals attributes } \\
\hline $\mathrm{pH}$ & 6.26 \\
\hline $\mathrm{P}\left(\mathrm{mg} \mathrm{dm}^{-3}\right)$ & 11.35 \\
\hline $\mathrm{K}^{+}\left(\mathrm{mg} \mathrm{dm}^{-3}\right)$ & 40 \\
\hline $\mathrm{Na}^{+}\left(\mathrm{cmol} \mathrm{dm}^{-3}\right)$ & 0.22 \\
\hline $\mathrm{H}^{+}+\mathrm{Al}^{+3}\left(\mathrm{cmol} \mathrm{dm}^{-3}\right)$ & 1.82 \\
\hline $\mathrm{Al}^{+3}\left(\mathrm{cmol} \mathrm{dm}^{-3}\right)$ & 0 \\
\hline $\mathrm{Ca}+2\left(\mathrm{cmol} \mathrm{dm}^{-3}\right)$ & 3 \\
\hline $\mathrm{Mg}\left(\mathrm{cmol} \mathrm{dm}^{-3}\right)$ & 1.9 \\
\hline $\mathrm{BS}\left(\mathrm{cmol} \mathrm{dm}^{-3}\right)$ & 5.22 \\
\hline $\mathrm{CEC}\left(\mathrm{cmol} \mathrm{dm}^{-3}\right)$ & 7.03 \\
\hline $\mathrm{V}(\%)$ & 74.34 \\
\hline $\mathrm{M}(\%)$ & 0 \\
\hline $\mathrm{OM}\left(\mathrm{g} \mathrm{Kg}^{-1}\right)$ & 17.53 \\
\hline
\end{tabular}

\section{Physical attributes}

\begin{tabular}{|l|c|}
\hline Ds & 1.38 \\
\hline Pd & 2.67 \\
\hline Tp & 0.48 \\
\hline CC & 78 \\
\hline PMP $\left(\mathrm{g} \mathrm{g}^{-1}\right)$ & 43 \\
\hline Sand $\left(\mathrm{g} \mathrm{kg}^{-1}\right)$ & 756.9 \\
\hline Silt $\left(\mathrm{g} \mathrm{kg}^{-1}\right)$ & 59.1 \\
\hline Clay $\left(\mathrm{g} \mathrm{kg}^{-1}\right)$ & 184 \\
\hline- & - \\
\hline- & - \\
\hline- & - \\
\hline - & - \\
\hline $\begin{array}{l}\text { Textural } \\
\text { classification }\end{array}$ & $\begin{array}{c}\text { Sandy } \\
\text { franc }\end{array}$ \\
\hline
\end{tabular}

Base sum (BS) $=\left(\mathrm{Na}^{+}+\mathrm{K}^{+}+\mathrm{Ca}^{2+}+\mathrm{Mg}^{2+}\right) ; \mathrm{CEC}=$ cation exchange capacity; $\mathrm{EC}=\mathrm{BS}+\left(\mathrm{H}^{+}+\mathrm{Al}^{3+}\right) ; \mathrm{V}=(100 \times \mathrm{BS} / \mathrm{CEC}) ; \mathrm{OM}=$ organic matter. Ds $=$ density of the soil; $\mathrm{Pd}=$ particle density; $\mathrm{Tp}=$ total porosity; (1- (Ds/Dp) * 100) Ucc $=$ volumetric humidity level of field capacity - $0.033 \mathrm{MPa}$; Upmp = humidity level of the permanent wilting point - $1.5 \mathrm{MPa}$.

Table 3. Chemical characteristics of the water.

\begin{tabular}{|c|c|c|c|c|c|}
\hline \multirow{3}{*}{ Attributes } & \multicolumn{5}{|c|}{ Electric conductivity $\left(\mathrm{dS} \mathrm{m}^{-1}\right)$} \\
\hline & 0.50 & 1.30 & 3.25 & 5.20 & 6.00 \\
\hline & \multicolumn{5}{|c|}{ Values } \\
\hline $\mathrm{pH}$ & 7.00 & 7.50 & 7.40 & 7.30 & 7.40 \\
\hline $\mathrm{SO}_{4}^{-2}$ & 3.22 & 3.70 & 3.67 & 3.35 & 3.90 \\
\hline $\mathrm{Mg}^{2+}$ & 1.33 & 1.78 & 1.93 & 2.03 & 2.98 \\
\hline $\mathrm{Na}^{+}$ & 1.70 & 5.92 & 12.57 & 20.5 & 24.20 \\
\hline $\mathrm{K}^{+}$ & 0.20 & 0.21 & 0.20 & 0.20 & 0.21 \\
\hline $\mathrm{Ca}^{2+}$ & 0.73 & 1.58 & 1.78 & 1.88 & 2.53 \\
\hline $\mathrm{CO}_{3}^{-2}$ & 0.00 & 0.00 & 0.00 & 0.00 & 0.00 \\
\hline $\mathrm{HCO}_{3}^{-}$ & 2.75 & 3.50 & 4.00 & 4.25 & 4.25 \\
\hline $\mathrm{Cl}^{-}$ & 3.40 & 10.90 & 30.40 & 48.90 & 58.15 \\
\hline SAR $\left(\mathrm{mmol} \mathrm{L}^{-1}\right)^{0.5}$ & 1.28 & 1.87 & 2.60 & 3.23 & 2.96 \\
\hline Classification & C2S1 & C3S3 & C4S4 & C4S4 & C4S4 \\
\hline
\end{tabular}

$\mathrm{EC}=$ electrical conductivity at $25^{\circ} \mathrm{C} ; \mathrm{SAR}=$ sodium adsorption ratio $\left[\mathrm{Na}^{+} /\right.$ $\left.\left(\mathrm{Ca}^{2+}+\mathrm{Mg}^{2+} / 2\right)^{1 / 2}\right] ; \mathrm{CO}_{3}{ }^{2-}=$ Absent. Water classification according to Richards (1954)

water with different salinities was initiated $10 \mathrm{~d}$ after emergence. On the first day after emergence (DAE), the blade was calculated with the equation proposed 
by Mantovani et al. (2009); the total required irrigation (TRI) was calculated with the equation by Bernardo et al. (2008), considering 100\% of irrigation application efficiency.

The silicon was applied in the liquid potassium silicate form $\left(\mathrm{K}_{2} \mathrm{SiO}_{3}\right)$ with $12 \% \mathrm{Si}$ and $15 \% \mathrm{~K}_{2} \mathrm{O}$. The $\mathrm{Si}$ doses were applied via the soil. However, there was compensation of $\mathrm{K}_{2} \mathrm{O}$ via soil, the application used in the beet aiming to provide the same amount of potassium to all plants. The application was done weekly, totaling 7 applications during the development and production of beets. The doses (Si) were diluted in 1.2 $\mathrm{L}$ of distilled water, and $50 \mathrm{~mL}$ of this solution were applied to each plant.

During the experiment, weather data (Fig. 1) were recorded daily with a digital thermo hygrometer, HT-600 Instruthermr ${ }^{\circledR}$, installed in the experimental area, at the height of the plants. The average air temperature was near the ideal range $\left(25^{\circ} \mathrm{C}\right)$ during the crop cycle, according to Filgueiras (2008).

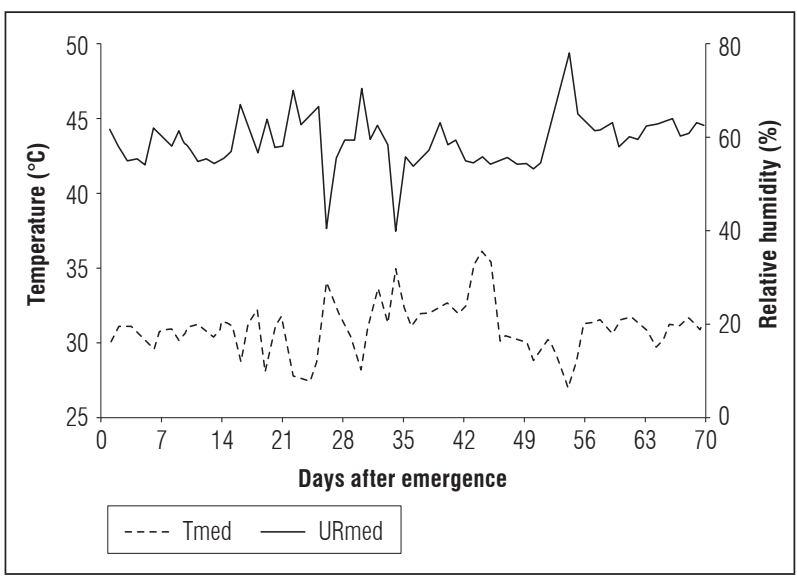

Figure 1. Graphical representation of relative humidity and temperature in the experiment. Mean Air temperature (Tmed) and mean relative humidity (URmed).

The fertilizer at sowing and covering was done with 40, 180 and $90 \mathrm{~kg} \mathrm{ha}^{-1}$ of NPK, with urea, superphosphate and potassium chloride, according to the chemical analysis of the soil and fertilizer recommendations for State of Pernambuco, Brazil (IPA, 2008). During the conduction of the experiment phytosanitary controls of pests and weeds were made.

The growth of the beet plants was evaluated by measuring plant height (measured with a ruler graduated in $\mathrm{cm}$ ), leaf area ((by measuring the length $(\mathrm{C})$ and width (L), and by applying in the AF formula $=\mathrm{C} * \mathrm{~L}$
* $\mathrm{f}$, with $\mathrm{AF}=$ leaf area in $\mathrm{m}^{2} ; \mathrm{C}=$ length of the leaf in $\mathrm{m}$; $\mathrm{L}=$ leaf width in $\mathrm{m}$; and $\mathrm{f}=$ correction factor for beets (0.692), according to Simões et al. (2016)), number of leaves, and leaf length and width (using digital caliper) at $60 \mathrm{~d}$ after emergence.

At the end of the experiment, measurements were taken: longitudinal and transversal diameter of the bulb (using digital caliper); bulb fresh mass, leaf fresh mass, leaf dry mass, root dry mass, fresh mass bulb (through weighing on an analytical balance), leaf chlorophyll indices $\mathrm{a}, \mathrm{b}$, total and $\mathrm{a} / \mathrm{b}$ ratio with $\mathrm{a}$ Clorofilog ${ }^{\circledR}$ chlorophyll meter (Falker). The readings were taken with intermediate leaves of the four central plants in the experiment area, performing four readings per plant.

The initial fluorescence $\left(\mathrm{F}_{0}\right)$, maximal fluorescence $\left(F_{m}\right)$, variable fluorescence $\left(F_{v}\right)$ and quantum efficiency of photosystem II $\left(\mathrm{F}_{\mathrm{v}} / \mathrm{F}_{\mathrm{m}}\right)$ were also evaluated using a portable fluorometer (PEA - Plant Efficiency Analyzer, Hansatech).

The data were subjected to analysis of variance, and, when significant, the data were subjected to polynomial regression analysis $(P \leq 0.05)$. For the data that were not significant, standard deviations of the mean were carried out. The SAS University (Cody, 2015) software was used for these analyses.

\section{RESULTS AND DISCUSSION}

Plant height was adjusted to a quadratic model as a function of salinity in the irrigation water. There was a reduction in plant height with the increasing salt concentrations, reaching the point of maximum efficiency when the plants were irrigated with $0.40 \mathrm{dS}$ $\mathrm{m}^{-1}$, corresponding to a height of $27.50 \mathrm{~cm}$; the plant height was reduced when irrigation was done with high salinity water (Fig. 2A).

A reduction in plant height was also observed by Silva et al. (2015), who found that the greatest height of beet cv. Itaapuã plants was $43.6 \mathrm{~cm}$ with $6 \mathrm{dS} \mathrm{m} \mathrm{m}^{-1}$ irrigation water, with a reduction with increasing salinity. Santos et al. (2016) observed that the maxi-

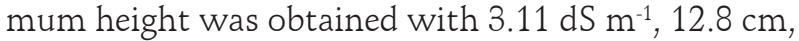
confirming the results obtained in this study, i.e. the increased salinity in the irrigation water significantly reduced the height of the plants.

The same behavior was observed for the leaf area, which decreased as salinity increased. The largest leaf area was $3720.75 \mathrm{~cm}^{2}$, in the plants irrigated 
with $0.5 \mathrm{dS} \mathrm{m} \mathrm{m}^{-1}$ water (Fig. 2B). This reduction may have been caused by morphological and physiological changes, one of the first symptoms being a reduction in leaf area, which is a way to increase tolerance to salinity.

Santos et al. (2016) observed that the maximum leaf area was obtained with a salinity of $2.85 \mathrm{dS} \mathrm{m}^{-1}, 21$ $4 \mathrm{~cm}^{2}$. This result is lower than that obtained in the present study. In studies on radish crops, Oliveira et al. (2012) found that the greatest leaf area value was observed in plants irrigated with lower salinity water
(2 $\mathrm{dS} \mathrm{m} \mathrm{m}^{-1}$ ), yielding $497.20 \mathrm{~cm}^{2}$, while the highest ECw $\left(10 \mathrm{dS} \mathrm{m}^{-1}\right)$ resulted in a smaller leaf area, 220 $\mathrm{cm}^{2}$, a reduction of $55.75 \%$, corroborating the data obtained in this study.

The bulb diameter and the bulb longitudinal diameter decreased when the beet plants were irrigated with saline water, decreases with increasing salt. Larger diameters were obtained with plants irrigated with water with a lower salinity, yielding $31.26 \mathrm{~mm}$ with $0.10 \mathrm{dS} \mathrm{m}^{-1}$ irrigation water (Fig. 2C) and 32.56 $\mathrm{mm}$ with $0.15 \mathrm{dS} \mathrm{m}^{-1}$ water (Fig. 2D).
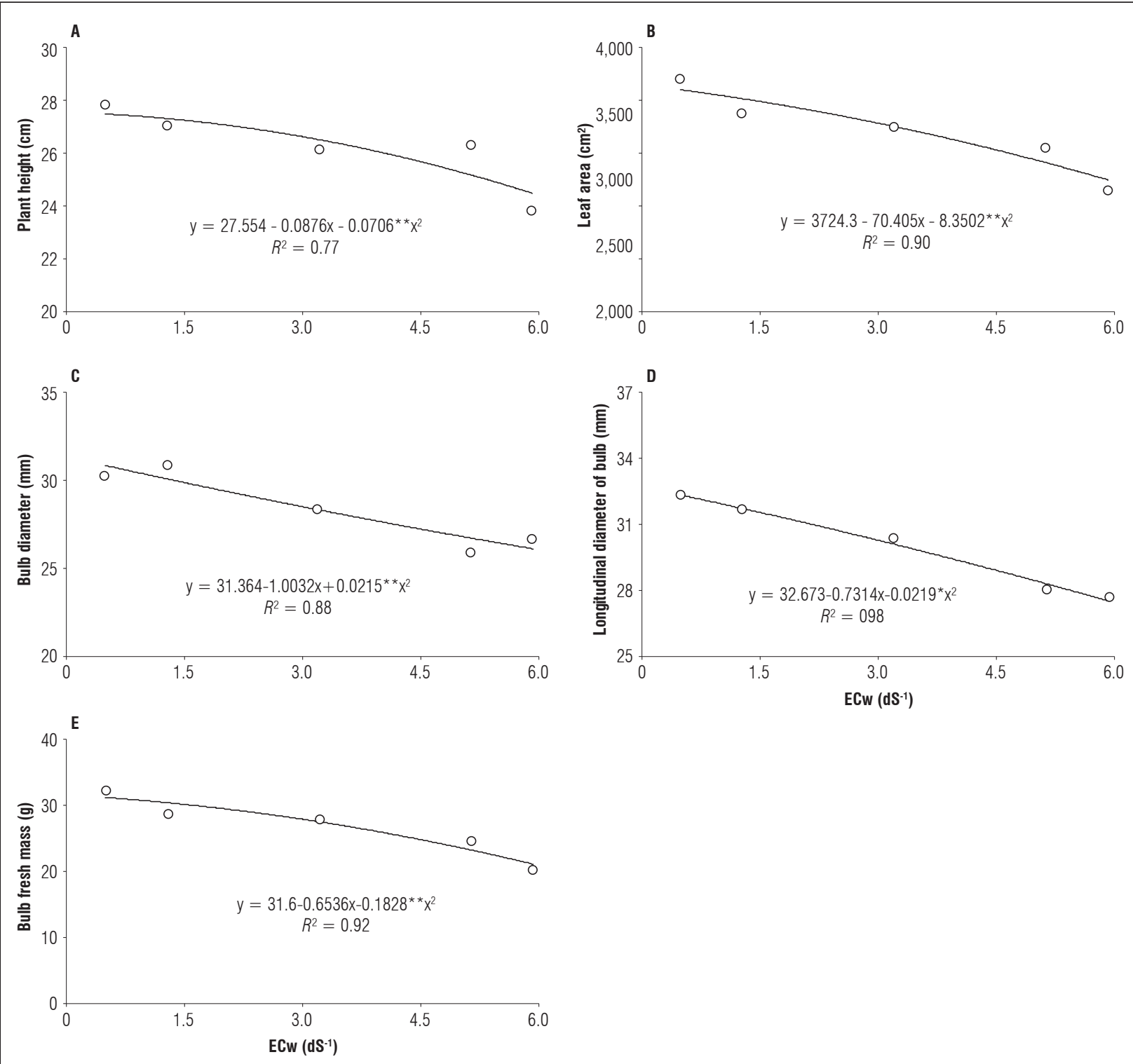

Figure 2. Plant height (A), leaf area (B), bulb diameter (C), bulb longitudinal diameter (D) and fresh bulb mass (E) of beet plants irrigated with water with different electrical conductivities. 
The bulb fresh mass also decreased with the increased salts in the irrigation water; the largest bulb fresh mass was $31.49 \mathrm{~g}$ when the beet plants were irrigated with $0.14 \mathrm{dS} \mathrm{m}^{-1}$ (Fig. 2E).

The results obtained in this present study agree with those of Silva et al. (2015) who studied the management of fertigation and soil salinity in terms of growth in a beet culture, observing that increasing the salinity of the water reduced the beet plant bulb diameter.

The salinity in the irrigation water did not significantly affect the analyzed variables (Tab. 4). Howev$\mathrm{er}$, the highest values were observed in the beet plants irrigated with low salinity water $\left(0.50 \mathrm{dS} \mathrm{m}^{-1}\right)$, and, although no significant effect was found, the lowest values were observed with higher salinity irrigation water $\left(6.00 \mathrm{dS} \mathrm{m}^{-1}\right)$, proving that the salt stress dramatically reduced the growth and development of the plants, as was observed by Silva et al. (2015) and Santos et al. (2016) in beets, and by Shi et al. (2013), Lima et al. (2014) and Reis et al. (2016) in rice, roses and castor, respectively.

By irrigating the beet plants with $6.00 \mathrm{dS} \mathrm{m}^{-1}$ water, smaller values were obtained for leaf fresh mass, leaf dry mass and root dry mass, which may have been caused by a decrease in osmotic potential, the soil solution, and the excessive accumulation of salts, inhibiting the absorption of water from the beet plants and, as a result, requiring greater energy for the absorption of water and nutrients and reducing growth and biomass accumulation (Sá et al., 2015; Bertazzini et al., 2018).

Table 4. Mean \pm standard deviation of the variables leaf width (WI), leaf length (LI), leaf area (La), number of leaves (NI), chlorophyll content A (CI a), chlorophyll B (CI b), total chlorophyll (Total Cl), chlorophyll a/b ratio (CI a/b), leaf fresh mass (Lmf), leaf dry mass (Ldm), root dry mass $(\mathrm{Rdm})$, cross bulb diameter $(C b d)$, initial fluorescence $\left(\mathrm{F}_{0}\right)$, maximal fluorescence $\left(F_{m}\right)$, variable fluorescence $\left(F_{v}\right)$ and quantum efficiency of photosystem $I\left(F_{v} / F_{m}\right)$ of beet plants as a function of irrigation with saline water (ECw).

\begin{tabular}{|c|c|c|c|c|}
\hline \multirow{2}{*}{$\mathrm{ECw}\left(\mathrm{dS} \mathrm{m}^{-1}\right)$} & \multicolumn{4}{|c|}{ Variables } \\
\hline & WI & $\mathrm{LI}$ & La & $\mathrm{NI}$ \\
\hline 0.50 & $62.71 \pm 9.51$ & $123.06 \pm 15.48$ & $5,398.06 \pm 15.02$ & $9.91 \pm 1.67$ \\
\hline 1.30 & $60.52 \pm 15.22$ & $105.72 \pm 22.01$ & $4,762.31 \pm 10.02$ & $10.20 \pm 1.92$ \\
\hline 3.25 & $56.09 \pm 16.23$ & $95.14 \pm 21.99$ & $3,821.68 \pm 18.23$ & $10.11 \pm 1.08$ \\
\hline 5.20 & $55.88 \pm 13.56$ & $103.82 \pm 18.85$ & $3,822.55 \pm 17.15$ & $9.95 \pm 1.57$ \\
\hline \multirow[t]{2}{*}{6.00} & $51.65 \pm 17.51$ & $83.99 \pm 26.40$ & $3,284.99 \pm 9.16$ & $9.91 \pm 1.67$ \\
\hline & $\mathrm{Cla}$ & $\mathrm{Cl} b$ & Total $\mathrm{Cl}$ & $\mathrm{Cl} a / b$ \\
\hline 0.50 & $38.00 \pm 4.84$ & $17.67 \pm 4.53$ & $53.67 \pm 9.10$ & $2.15 \pm 0.51$ \\
\hline 1.30 & $36.62 \pm 2.62$ & $18.40 \pm 4.08$ & $55.03 \pm 6.11$ & $2.08 \pm 0.32$ \\
\hline 3.25 & $35.36 \pm 4.31$ & $17.70 \pm 3.92$ & $53.06 \pm 8.08$ & $2.13 \pm 0.49$ \\
\hline 5.20 & $35.23 \pm 2.79$ & $17.16 \pm 4.50$ & $52.40 \pm 6.95$ & $2.20 \pm 0.33$ \\
\hline \multirow[t]{2}{*}{6.00} & $35.42 \pm 3.88$ & $13.06 \pm 7.35$ & $51.49 \pm 10.81$ & $1.76 \pm 0.36$ \\
\hline & Lmf & $\mathrm{Ldm}$ & Rdm & Cbd \\
\hline 0.50 & $32.80 \pm 10.92$ & $11.72 \pm 6.35$ & $0.12 \pm 0.09$ & $55.32 \pm 9.65$ \\
\hline 1.30 & $29.50 \pm 13.76$ & $9.40 \pm 6.35$ & $0.17 \pm 0.17$ & $54.19 \pm 7.07$ \\
\hline 3.25 & $27.93 \pm 9.17$ & $9.20 \pm 4.43$ & $0.13 \pm 0.08$ & $53.85 \pm 8.97$ \\
\hline 5.20 & $28.44 \pm 15.67$ & $11.29 \pm 7.92$ & $0.17 \pm 0.08$ & $54.52 \pm 11.37$ \\
\hline \multirow[t]{2}{*}{6.00} & $21.37 \pm 7.89$ & $8.74 \pm 5.82$ & $0.11 \pm 0.11$ & $46.35 \pm 5.26$ \\
\hline & $\mathrm{F}_{0}$ & $\mathrm{Fm}$ & $\mathrm{Fv}$ & $\mathrm{Fv} / \mathrm{Fm}$ \\
\hline 0.50 & $78.19 \pm 12.8$ & $332.38 \pm 10.52$ & $294.19 \pm 11.17$ & $0.95 \pm 0.07$ \\
\hline 1.30 & $62.88 \pm 10.51$ & $318.97 \pm 11.17$ & $256.09 \pm 12.10$ & $0.79 \pm 0.09$ \\
\hline 3.25 & $65.75 \pm 11.87$ & $317.77 \pm 11.53$ & $252.02 \pm 9.14$ & $0.80 \pm 0.06$ \\
\hline 5.20 & $74.13 \pm 15.71$ & $313.66 \pm 12.19$ & $239.53 \pm 13.51$ & $0.77 \pm 0.08$ \\
\hline 6.00 & $56.94 \pm 9.17$ & $318.44 \pm 14.28$ & $2,371.50 \pm 10.19$ & $0.73 \pm 0.02$ \\
\hline
\end{tabular}


The smallest values for the chlorophyll contents $\mathrm{a}, \mathrm{b}$ and total chlorophyll a and fluorescence photochemical efficiency of photosystem II when the plants were irrigated with water with higher salinity $(6.00$ $\mathrm{dS} \mathrm{m}^{-1}$ ) were due to the reduction in the activity of photosynthetic enzymes, limiting the electron transport in the chloroplasts. The accumulation of $\mathrm{Na}^{+}$ and $\mathrm{Cl}^{-1}$ in chloroplasts changes the photosynthetic activity of plants, which reduces the photochemical efficiency of photosystem II (Huang et al., 2012).

The same behavior was observed by Silva et al. (2013), who found a decrease in the growth and physiological parameters of beet cv. Early Wonder with increased salinity. Silva et al. (2015) also found that the salinity in irrigation water reduced the growth of beet plants.

It was observed that the leaf area decreased with the increase of the silicon doses, up to $9.08 \mathrm{~mL} \mathrm{~L}^{-1}$, with a subsequent increase up to $18.16 \mathrm{~mL} \mathrm{~L}^{-1}$, reaching a maximum leaf area of $3591.15 \mathrm{~cm}^{2}$ with $0.26 \mathrm{~mL} \mathrm{~L}^{-1}$ (Fig. 3A). The longitudinal diameter of the bulbs presented the same behavior, with the greatest longitudinal diameter, $32.45 \mathrm{~mm}$, observed in the plants treated with $0.24 \mathrm{~mL} \mathrm{~L}^{-1}$ of silicon (Fig. 3B).
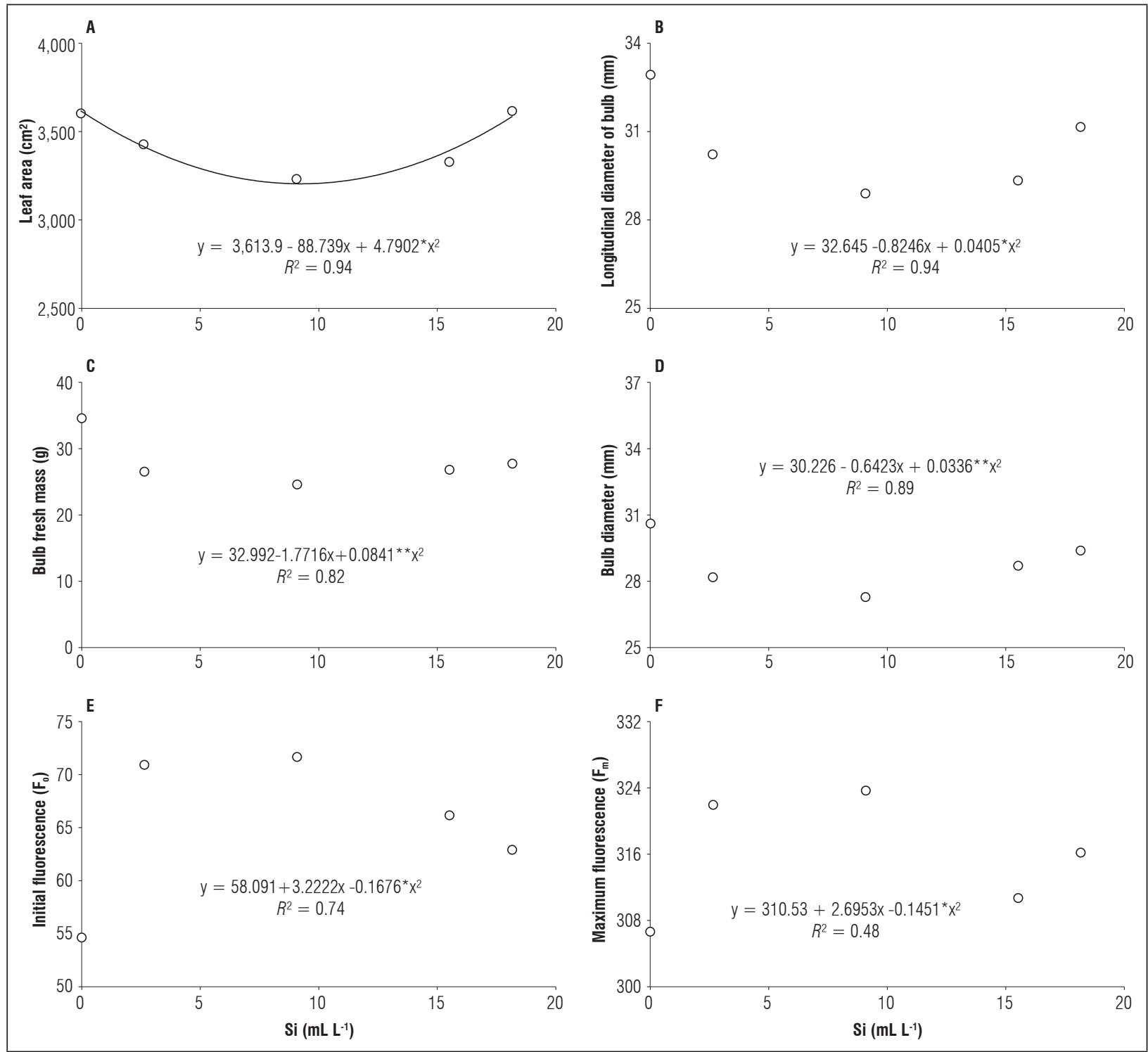

Figure 3. Longitudinal diameter of the bulbs (B), bulb fresh mass (C), bulb diameter (D), initial fluorescence (E) and maximum fluorescence $(F)$ in beet plants for the different doses of leaf silicon. 
The fresh mass of the bulb and the bulb diameter decreased with increased doses of silicon, up to $9.08 \mathrm{~mL}$ $\mathrm{L}^{-1}$; however, higher doses of $\mathrm{Si}$ increased these variables. The highest values for bulb fresh mass (Fig. 3C) and bulb diameter (Fig. 3D) were obtained when the plants received $0.23 \mathrm{~mL} \mathrm{~L}^{-1}$ and $0.26 \mathrm{~mL} \mathrm{~L}^{-1}$, yielding $32.60 \mathrm{~g}$ and $30.06 \mathrm{~mm}$.

The initial fluorescence and maximum fluorescence increased with doses up to $9.08 \mathrm{~mL} \mathrm{~L}^{-1}$, with reductions over this dose. The highest values were observed when applying $9.08 \mathrm{~mL} \mathrm{~L}^{-1}$ with values of 71.63 (Fig. 3E) and 323.75 (Fig. 3F), respectively.

The silicon doses did not influence the analyzed variables (Tab. 5). However, the dose of $9.08 \mathrm{~mL} \mathrm{~L}^{-1}$ promoted higher contents of chlorophyll a, b, and total, and a higher dose $\left(18.16 \mathrm{~mL} \mathrm{~L}^{-1}\right)$ provided higher chlorophyll fluorescence $\left(\mathrm{F}_{\mathrm{v}}\right)$ and quantum efficiency of photosystem II $\left(\mathrm{F}_{\mathrm{v}} / \mathrm{F}_{\mathrm{m}}\right)$, indicating that Si may mitigate the effect of salt stress because of the increase of photosynthetic pigments (Rezende et al., 2018).
Although there was not a significant effect on the analyzed variables, greater values of chlorophyll $a, b$ and total, fluorescence $\left(F_{v}\right)$ and quantum efficiency of photosystem II $\left(\mathrm{F}_{\mathrm{v}} / \mathrm{F}_{\mathrm{m}}\right)$ confirmed that $\mathrm{Si}$ has a significant influence on the photosynthesis and biochemistry of plants. Several studies have demonstrated the positive effect of $\mathrm{Si}$, as reported by Bae et al. (2012), Tahir et al. (2012) and Yin et al. (2013), who found that an increased availability of $\mathrm{Si}$ increases growth, photosynthetic and biochemical aspects of plants.

As noted in this study, several studies have shown that Si promotes growth and photosynthetic activity (Bae et al., 2012; Tahir et al., 2012; Yin et al., 2013); leaves become more erect, allowing a greater absorption of $\mathrm{CO}_{2}$ and higher photosynthetic efficiency and chlorophyll contents. Si accumulation on the leaf surface may have promoted a physical barrier in the leaves of the beet plants, playing an important role in osmotic adjustment (Heckman, 2013; Cantuário et al., 2014).

\section{Table 5. Mean \pm standard deviation of the variables plant height $(\mathrm{Ph})$, leaf width (WI), leaf length (LI), number of leaves (NI), chlorophyll content a (Cl a), chlorophyll b (CI b), total chlorophyll (Total CI), chlorophyll $a / b$ ratio $(\mathrm{Cl} a / b)$, fluorescence $\left(F_{v}\right)$, quantum efficiency photosystem $\left(F_{v} / F_{m}\right)$, leaf fresh mass $(\mathrm{Lfm})$, leaf dry mass $(\mathrm{Ldm})$, root dry mass $(\operatorname{Rdm})$ and transverse bulb diameter (Tdm) of beet plants under silicon applications via the soil.}

\begin{tabular}{|c|c|c|c|c|c|}
\hline \multirow{2}{*}{ Si $\left(m L ~ L^{-1}\right)$} & \multicolumn{5}{|c|}{ Variables } \\
\hline & $\mathrm{Ph}$ & WI & $\mathrm{LI}$ & $\mathrm{NI}$ & $\mathrm{Cla}$ \\
\hline 0.00 & $26.05 \pm 2.93$ & $59.55 \pm 15.07$ & $98.90 \pm 24.44$ & $10.25 \pm 1.22$ & $35.05 \pm 3.00$ \\
\hline 2.64 & $27.06 \pm 3.86$ & $58.90 \pm 23.41$ & $101.10 \pm 27.04$ & $10.08 \pm 1.56$ & $36.02 \pm 4.54$ \\
\hline 9.08 & $25.82 \pm 3.50$ & $54.88 \pm 16.45$ & $90.83 \pm 26.46$ & $9.94 \pm 1.45$ & $36.80 \pm 4.17$ \\
\hline 15.52 & $26.25 \pm 3.95$ & $57.50 \pm 18.41$ & $128.43 \pm 28.10$ & $10.08 \pm 1.61$ & $35.84 \pm 3.78$ \\
\hline \multirow[t]{2}{*}{18.16} & $26.43 \pm 3.63$ & $58.42 \pm 16.09$ & $101.08 \pm 26.15$ & $10.08 \pm 1.73$ & $35.05 \pm 6.53$ \\
\hline & $\mathrm{Cl} b$ & Total Cl & $\mathrm{Cl} a / b$ & $\mathrm{~F}_{\mathrm{v}}$ & $\mathrm{F}_{\mathrm{v}} / \mathrm{F}_{\mathrm{m}}$ \\
\hline 0.00 & $18.87 \pm 6.54$ & $53.93 \pm 9.15$ & $2.01 \pm 0.52$ & $222.25 \pm 12.1$ & $0.80 \pm 0.51$ \\
\hline 2.64 & $18.18 \pm 5.34$ & $54.21 \pm 9.54$ & $2.12 \pm 0.52$ & $233.63 \pm 10.5$ & $0.79 \pm 0.43$ \\
\hline 9.08 & $19.31 \pm 5.84$ & $56.11 \pm 9.50$ & $2.02 \pm 0.43$ & $235.75 \pm 12.14$ & $0.77 \pm 0.86$ \\
\hline 15.52 & $17.38 \pm 5.04$ & $53.22 \pm 8.36$ & $2.16 \pm 0.39$ & $198.50 \pm 12.75$ & $0.69 \pm 0.74$ \\
\hline \multirow[t]{2}{*}{18.16} & $17.03 \pm 6.10$ & $52.09 \pm 12.34$ & $2.25 \pm 0.61$ & $238.00 \pm 12.53$ & $0.81 \pm 0.17$ \\
\hline & $\mathrm{Lfm}$ & $\mathrm{Ldm}$ & $\mathrm{Rdm}$ & $\mathrm{Tdm}$ & \\
\hline 0.00 & $31.77 \pm 11.79$ & $10.59 \pm 5.55$ & $0.17 \pm 0.11$ & $57.39 \pm 7.66$ & \\
\hline 2.64 & $30.22 \pm 15.83$ & $10.66 \pm 6.88$ & $0.16 \pm 0.15$ & $55.40 \pm 11.58$ & \\
\hline 9.08 & $26.57 \pm 11.17$ & $9.89 \pm 5.75$ & $0.13 \pm 0.09$ & $51.03 \pm 7.98$ & \\
\hline 15.52 & $27.72 \pm 13.39$ & $10.03 \pm 6.68$ & $0.18 \pm 0.13$ & $53.31 \pm 9.47$ & \\
\hline 18.16 & $26.48 \pm 11.17$ & $7.79 \pm 4.10$ & $0.11 \pm 0.05$ & $50.74 \pm 9.31$ & \\
\hline
\end{tabular}




\section{CONCLUSION}

The increase of electrical conductivity in the irrigation water reduced the growth and production of the beets, but the chlorophyll contents, biomass production and fluorescence were not influenced by irrigation with saline water.

The application of silicon in the soil promoted increases in growth and chlorophyll fluorescence a; however, it did not reduce the harmful effect of salt stress.

Electrical conductivity in the irrigation water above $0.50 \mathrm{dS} \mathrm{m}^{-1}$ adversely affected the beet cultivation, and the silicon dose of $9.08 \mathrm{~mL} \mathrm{~L}^{-1}$ is recommended for applications.

Conflict of interests: this manuscript was prepared and reviewed with the participation of all authors, who declare that there exists no conflict of interest that puts at risk the validity of the presented results.

\section{BIBLIOGRAPHIC REFERENCES}

Bae, E.J., K.S. Lee, M.R. Huh, and C.S. Lim. 2012. Silicon significantly alleviates the growth inhibitory effects of $\mathrm{NaCl}$ in salt-sensitive 'Perfection' and 'Midnight' Kentucky bluegrass (Poa pratensis L.). Hortic. Environ. Biotechnol. 53(6), 477-483. Doi: 10.1007/ s13580-012-0094-3

Bernardo, S., A.A. Soares, and I.E.C. Mantovan. 2008. Manual de irrigação. $8^{\text {th }} \mathrm{ed}$. Ed. UFV, Viçosa, Brazil.

Bertazzini, M., G.A. Sacchi, and G.A. Forlani. 2018. Differential tolerance to mild salt stress conditions among six Italian rice genotypes does not rely on $\mathrm{Na}^{+}$exclusion from shoots. J. Plant Physiol. 226, 145-153. Doi: 10.1016/j.jplph.2018.04.011

Cantuário, F.S., J.M.Q. Luz, A.I.A. Pereira, L.C. Salomão, and T.N.H. Rebouças. 2014. Podridão apical e escaldadura em frutos de pimentão submetidos a estresse hídrico e doses de silício. Hort. Bras. 32, 215-219. Doi: 10.1590/S0102-05362014000200017

Castellanos, C.I., M.P.D. Rosa, C. Deuner, A. Bohn, A. C. Barros, and G.E. Meneghello. 2016. Aplicação ao solo de cinza de casca de arroz como fonte de silício: efeito na qualidade de sementes de trigo produzidas sob stresse salino. Rev. Ciênc. Agrár. 39(1), 95-104. Doi: 10.19084/RCA15011

Cody, R. 2015. An introduction to SAS. SAS Institute, Cary, NC.
Dias, N.S. and F.F. Blanco. 2010. Efeito dos sais no solo e na planta. In: Gheyi, H.R., N.S. Dias, and C.F. Lacerda (eds). Manejo da salinidade na agricultura: estudos básicos e aplicados. INCT Sal, Fortaleza, Brazil.

EMBRAPA, Empresa Brasileira de Pesquisa Agropecuária. 2014. Sistema brasileiro de classificação de solo. $4^{\text {th }} \mathrm{ed}$. Embrapa Solos, Brasilia.

Filgueira, F.A.R. 2008. Novo manual de olericultura: Agrotecnologia moderna na produção e comercialização de hortaliças. $2^{\text {nd }}$ ed. UFV, Viçosa, Brazil.

Fraire-Velázquez, S. and V.E. Balderas-Hernández. 2013. Abiotic stress in plants and metabolic responses. pp. 25-48. In: Vahdati, K. and C. Leslie (Org.). Abiotic stress-plant responses and applications in agriculture. IntechOpen, London. Doi: 10.5772/54859

Heckman, J. 2013. Silicon: a beneficial substance. Better Crops 97(4), 14-16.

Huang, Z., X. Long, L. Wang, J. Kang, Z. Zhang, R. Zed, and Z. Liu. 2012. Growth, photosynthesis and $\mathrm{H}^{+}$-ATPase activity in two Jerusalem artichoke varieties under $\mathrm{NaCl}$-induced stress. Process Biochem. 47(4), 591-596. Doi: $10.1016 /$ j.procbio.2011.12.016

IPA, Instituto Agronômico de Pernambuco. 2008. Recomendação de adubação para o Estado de Pernambuco: $2^{\circ}$ aproximação. $3^{\text {rd }}$ ed. Instituto Agronômico de Pernambuco, Recife, Brazil.

Lima, G.S., R.G. Nobre, H.R. Gheyi, L.A. Anjos Soares, and A.O. Silva. 2014. Cultivo da mamoneira sob estresse salino e adubação nitrogenada. Eng. Agríc. 34(5), 854 866. Doi: 10.1590/S0100-69162014000500005

Mantovani, E.C., S. Bernardo, and L.F. Palaretti. 2009. Irrigação: princípios e métodos. Ed. UFV, Viçosa, Brazil.

Mateus, N.B., D. Barbin, and A. Conagin. 2001. Viabilidade de uso do delineamento composto central. Acta Sci. Agron. 23(6), 1537-1546.

Oliveira, A.M.P., A.D. Oliveira, N.D.S. Dias, M. Freitas, and K.D. Silva. 2012. Cultivo de rabanete irrigado com água salina. Rev. Verde Agroec. Des. Sust. 7, 01-05.

Pedrotti, A., R.M. Chagas, V.C. Ramos, A.P. Nascimento Prata, A.A. T. Lucas, and P.B. Santos. 2015. Causas e consequências do processo de salinização dos solos. Rev. Elet. Gest. Ed. Tec. Amb. 19(2), 1308-1324.

Reis, M., J.R.M. Figueiredo, R. Paiva, D.P. Silva, C.V.N. Faria, and L. Rouhana. 2016. Salinity in rose production. Ornam. Hortic. 22(2), 228-234. Doi: 10.14295/ oh.v22i2.904

Rezende, R.A.L.S., F.A. Rodrigues, J.D.R. Soares, H.R D.O. Silveira, M. Pasqual, and G.D.M.G. Dias. 2018. Salt stress and exogenous silicon influence physiological and anatomical features of in vitro-grown cape gooseberry. Ciên. Rur. 48(1), 1-9. Doi: 10.1590/0103-8478cr20170176 
Richards, L.A. 1954. Diagnóstico e rehabilitación de suelos salinos e sódicos. Ed. Limusa, México DF.

Sá, F.V.S., M.E.B. Brito, L.A. Silva, R.C.L. Moreira, P.D. Fernandes, and L.C. Figueiredo. 2015. Fisiologia da percepção do estresse salino em híbridos de tangerineira - Sunki Comum sob solução hidropônica salinizada. Com. Sci 6(4), 463-470. Doi: 10.14295/cs.v6i4.1121

Sahebi, M., M.M. Hanafi, and P. Azizi. 2016. Application of silicon in plant tissue culture. In Vitro Cell. Dev. Biol.Plant 52(3), 226-232. Doi: 10.1007/s11627-016-9757-6

Santos, D.P., C.S. Santos, P.F. Silva, M.P.M.A. Pinheiro, and J.C. Santos. 2016. Crescimento e fitomassa da beterraba sob irrigação suplementar com água de diferentes concentrações salinas. Ceres 63(4), 509-516. Doi: 10.1590/0034-737X201663040011

Shi, Y., Y. Wang, T.J. Flowers, and H. Gong. 2013. Silicon decreases chloride transport in rice (Oryza sativa L.) in saline conditions. J. Plant Physiol. 170(9), 847-853. Doi: $10.1016 / j . j p l p h .2013 .01 .018$

Silva, A.O.D., A.E. Klar, E.F.D.F. Silva, A.A. Tanaka, S. Junior, and F. Josué. 2013. Relações hídricas em cultivares de beterraba em diferentes níveis de salinidade do solo. Rev. Bras. Eng. Agríc. Ambient. 17(10), 11431151. Doi: 10.1590/S1415-43662013001100003
Silva, A.O.D., Ê.F. Silva, and A.E. Klar. 2015. Manejo da fertirrigação e salinidade do solo no crescimento da cultura da beterraba. Eng. Agríc. 35(2), 230-241. Doi: 10.1590/1809-4430-Eng.Agric.v35n2p230-241/2015

Simões. W.L., M.A. Souza, J.E. Yuri, M.M. Guimarães, and V.H. Gomes. 2016. Desempenho de cultivares de beterrabas submetidas a diferentes lâminas de irrigação no Submédio São Francisco. Water Res. Irrig. Managem. 5(2), 51-57.

Syvertsena, J.P. and F. Garcia-Sanchez. 2014. Multiple abiotic stresses occurring with salinity stress in citrus. Environ Exp Bot. 103(1), 128-137. Doi: 10.1016/j. envexpbot.2013.09.015

Tahir, M.A., T. Aziz, M. Farooq, and G. Sarwar. 2012. Silicon-induced changes in growth, ionic composition, water relations, chlorophyll contents and membrane permeability in two salt-stressed wheat genotypes. Arch. Agron. Soil Sci. 58(3), 247-256. Doi: 10.1080/03650340.2010.518959

Yin, L., S. Wang, J. Li, K. Tanaka, and M. Oka. 2013. Application of silicon improves salt tolerance through ameliorating osmotic and ionic stresses in the seedling of Sorghum bicolor. Acta Physiol. Plant. 35(11), 3099-3107. Doi: 10.1007/s11738-013-1343-5 